\title{
ARTIKELEN
}

\section{Vrijheid van godsdienst en de grens tussen radicale en strafbare uitlatingen}

\author{
Aernout Nieuwenhuis
}

\begin{abstract}
De strafwet stelt bepaalde radicale uitlatingen strafbaar, zoals aanzetten tot haat en ronselen voor de gewapende strijd. Dergelijke uitlatingen kunnen godsdienstig gemotiveerd zijn. Deze bijdrage onderzoekt welke uitlatingen strafbaar zijn en wat de betekenis van de vrijheid van godsdienst - en van de vrijheid van meningsuiting - op dit gebied is.
\end{abstract}

\section{Inleiding}

Er bestaat al langere tijd bezorgdheid over de verspreiding van radicaal religieus en jihadistisch gedachtegoed. ${ }^{1}$ De aandacht richt zich onder meer op het salafisme, een fundamentalistische stroming binnen de soennitische islam. Deze stroming kent grofweg een drietal verschillende varianten: ${ }^{2}$ een apolitieke variant waarin een vroom persoonlijk leven centraal staat, een meer maatschappelijk en politiek betrokken richting die de democratie afwijst en de invoering van de sharia als ideaal ziet, en een verdergaande variant die andersgelovigen verkettert en gebruik van geweld te rechtvaardigen acht.

De bezorgdheid over de verspreiding van jihadistisch gedachtegoed is de afgelopen jaren toegenomen. ${ }^{3}$ Moslims die gebruik van geweld in Nederland afkeuren, kunnen op zijn minst ambivalent staan tegenover de in Syrië gevoerde strijd. ${ }^{4}$ Daarvoor ontvankelijke Nederlandse jongeren kunnen besluiten tot deelname aan strijd- en terreurgroepen in het Midden-Oosten. Wellicht nog zorgwekkender is dat ze na terugkomst in Nederland ook hier gewelddaden zouden kunnen begaan. In 2014 hebben de minister van Veiligheid en Justitie, de Nationaal Coördinator Terrorismebestrijding en Veiligheid en de minister van Sociale Zaken en Werkgelegenheid het actieprogramma 'Integrale Aanpak Jihadisme' opgesteld. Daarin vinden we naast maatregelen die gericht zijn op het voorkomen van aanslagen en maatregelen die discriminatie op de arbeidsmarkt moeten tegengaan, ook een reeks actiepunten die zien op het doen van radicale uitlatingen. Zo wordt het

1 Zie hierover B. de Graaf, 'Religion bites: religieuze orthodoxie op de nationale veiligheidsagenda', TvRRB 2011, 2, p. 62 e.v.

2 AIVD/NCTV, Salafisme in Nederland: diversiteit en dynamiek, Den Haag: AIVD/NCTV 2015, p. 5.

3 Vgl. AIVD, Weerstand en tegenkracht, Den Haag: AIVD 2009, bijlage bij Kamerstukken II 2009/10, 29924,45 . In deze notitie werd vastgesteld dat bepaalde salafistische moskeeën in rustiger vaarwater waren terechtgekomen, in elk geval wat de openlijke prediking betreft. 
ingrijpen bij haatzaaien - tegen welke bevolkingsgroep dan ook - en bij oproepen tot geweld geprioriteerd. ${ }^{5}$ Er wordt eveneens gewezen op het verbod te werven voor de gewapende strijd, en op een meldpunt voor mogelijk strafbare jihadistische content op internet.

Sommige politici menen overigens dat de bestaande strafbepalingen onvoldoende zijn om bepaalde jihadistische uitlatingen tegen te gaan. Zo heeft het CDA een voorstel gedaan om het verheerlijken van terrorisme strafbaar te stellen. Daarmee zouden bijvoorbeeld het meevoeren van IS-vlaggen en op internet verspreide blijken van instemming met de gruweldaden van ISIS aangepakt kunnen worden.

Er is in het actieprogramma ook aandacht voor radicale uitlatingen die op zichzelf niet strafbaar zijn, maar mogelijkerwijs wel als voedingsboden kunnen dienen voor verdergaande radicalisering in extremistische richting. ${ }^{6}$ Om die reden houdt de Algemene Inlichtingen- en Veiligheidsdienst (AIVD) bepaalde radicale stromingen - men denke bijvoorbeeld aan de eerdergenoemde richting binnen het salafisme die de democratie verwerpt, maar geweld afwijst - in de gaten. ${ }^{7}$ Zorg over radicale uitlatingen speelt ook een rol bij het al dan niet weigeren van een visum aan buitenlandse imams; hetzelfde geldt voor het intrekken van een verblijfsvergunning. ${ }^{8}$

Jihadistische en andere radicale uitlatingen kunnen religieus gemotiveerd zijn. Dat brengt de vraag met zich mee in hoeverre de in Nederland geldende en voorgestelde verboden zich verdragen met de vrijheid van godsdienst. Deze vraag valt in twee gedeelten uiteen. De eerste deelvraag is welke uitlatingen binnen de reikwijdte van het recht op vrijheid van godsdienst vallen. Bij een preek over het alziend oog van het Opperwezen zal daar weinig twijfel over bestaan; indien op grond van het geloof bepaalde politieke standpunten worden ingenomen, hoeft dat niet vanzelfsprekend te zijn. De tweede deelvraag is of de bestaande en voorgestelde strafbaarstelling van uitlatingen strookt met de vrijheid van godsdienst. De vraag of een uitlating binnen het bereik van de vrijheid van godsdienst valt, moet daarbij uitdrukkelijk onderscheiden worden van de vraag of het verbieden van die uitlating toelaatbaar is. Het recht op vrijheid van godsdienst mag immers beperkt worden indien aan bepaalde voorwaarden is voldaan. Men denke aan de grondwettelijke eis van een wet in formele zin (art. 6 lid 1 van de Grondwet (Gw)) en aan het vereiste in het Europees Verdrag voor de rechten van de mens (EVRM) dat een beperking 'noodzakelijk in een democratische samenleving' is (art. 9 lid 2 EVRM).

Deze twee deelvragen bepalen de opbouw van deze bijdrage. De eerstvolgende paragraaf ziet op de reikwijdte van de vrijheid van godsdienst en de verhouding met de vrijheid van meningsuiting. In de paragrafen daarna passeert een aantal relevante uitingsdelicten de revue: opruiing en bedreiging, groepsbelediging en het aanzetten tot discriminatie, haat en geweld, het werven voor de gewapende

5 NCTV, Actieprogramma Integrale Aanpak Jihadisme, Den Haag: NCTV 2014, p. 19.

6 NCTV 2014, p. 13.

7 Zie jaarverslagen AIVD; zie ook De Graaf 2011, p. 62 e.v.

8 Zie bijv. Antwoorden op vragen van leden van Tweede Kamer, door minister van Veiligheid en Justitie en minister van Buitenlandse Zaken d.d. 11 maart 2015, nr. 624381. 
strijd, en het voorgestelde verheerlijken. Ook is er kort aandacht voor het intrekken van een verblijfsvergunning dan wel het weigeren van een visum. Een conclusie sluit het geheel af.

\section{Grondrechtelijk kader}

\section{Vrijheid van godsdienst}

Artikel 9 EVRM beschermt naast het hebben - en het niet hebben - van een godsdienst de vrijheid om deze alleen of samen met anderen, zowel in het openbaar als in besloten kring, tot uitdrukking te brengen. De bepaling somt vier elementen van het belijden op: eredienst (worship), onderricht (teaching), praktische toepassing (practice) en het onderhouden van geboden (observance). Artikel $6 \mathrm{Gw}$ kent niet een soortgelijke opsomming, maar er mag van uit worden gegaan dat het gebruikte begrip 'belijden' een vergelijkbare reikwijdte heeft.

De term 'praktische toepassing' ziet overigens niet op iedere vorm van gedrag dat gemotiveerd of geïnspireerd wordt door een bepaalde godsdienst of overtuiging; ${ }^{9}$ er moet sprake zijn van een handeling die 'intimately linked' is aan de godsdienst. ${ }^{10}$ De Nederlandse rechter hanteert in dezen wel het criterium dat de handeling naar objectieve maatstaven een directe uitdrukking van de godsdienst dient te zijn. ${ }^{11}$

Het beschermde 'onderrichten' of 'uitdragen' omvat zowel het doorgeven van godsdienstige inzichten aan adepten als het, al dan niet in het openbaar, ${ }^{12}$ verkondigen van het geloof aan andersdenkenden. Het zal duidelijk zijn dat hier een overlap bestaat met de vrijheid van meningsuiting (art. 10 EVRM), die in beginsel alle uitlatingen beschermt. ${ }^{13}$ Uit de rechtspraak van het Europees Hof voor de Rechten van de Mens (EHRM) komt naar voren dat het recht op vrijheid van godsdienst in het bijzonder van toepassing is bij uitlatingen gedaan tijdens een religieuze bijeenkomst ${ }^{14}$ of bij het verkondigen en evangeliseren in eigenlijke zin. ${ }^{15}$

\section{Vrijheid van meningsuiting}

In andere gevallen heeft het EHRM religieus geïnspireerde uitlatingen beoordeeld op grond van artikel 10 EVRM. Dat gold onder meer voor de uitlatingen van een geestelijk leidsman die tijdens een heftig televisiedebat betoogde dat democratie en islam onverenigbaar zijn en dat de sharia moet worden ingevoerd. Nu lag een

9 EHRM 2 oktober 2001, 49853/99 (Pichon \& Sajous/France); EHRM 15 januari 2013, 48420/10 (Eweida/VK).

10 EHRM 15 januari 2013, 48420/10 (Eweida/VK).

11 ARRvS 7 april 1983, ECLI:NL:RVS:1983:AM7089 (Pensioenregeling huisartsen).

12 EHRM 25 mei 1993, 14307/88 (Kokkinakis/Griekenland).

13 Voor een pleidooi om de vrijheid van godsdienst min of meer op te laten gaan in de vrijheid van meningsuiting, zie R. Schutgens, 'Waarom de godsdienst- en de uitingsvrijheid moeten samensmelten', TvCR 2012, p. 96 e.v.

14 Bijv. EHRM 14 december 1999, 38178/97 (Serif/Greece); ook als deze bijeenkomst in een partijlokaal plaatsvindt: EHRM 2 december 2014, 31706/10 (Güler/Turkije).

15 Bijv. EHRM 25 mei 1993, 14307/88 (Kokkinakis/Griekenland) betreffende een mogelijkerwijs al te enthousiaste huis-aan-huis evangelisatie. 
beoordeling op grond van artikel 10 EVRM voor de hand, aangezien de klacht alleen de schending van deze bepaling betrof. ${ }^{16}$ Toch lijkt hier van een meer algemene lijn sprake te zijn. In het verleden heeft de Europese Commissie voor de Rechten van de Mens (ECRM) propaganda van politieke aard, ook al was die gebaseerd op een levensovertuiging, beoordeeld op grond van artikel 10 EVRM. ${ }^{17} \mathrm{Het}$ EHRM beoordeelde het verspreiden van propaganda voor de Algerijnse islamitische FIS expliciet alleen op grond van artikel 10 EVRM. ${ }^{18}$ De jurisprudentie op grond van artikel 10 EVRM is ook bij uitstek toegesneden op de beoordeling van een inmenging in het maatschappelijk debat. ${ }^{19}$

Het is de vraag in hoeverre de benadering van de Nederlandse rechter in dezen volledig vergelijkbaar en consistent is. ${ }^{20}$ Enerzijds werd de op het dak van een boerderij aangebrachte tekst 'Jezus redt' door de Afdeling bestuursrechtspraak van de Raad van State (ABRvS) met name beoordeeld op grond van artikel 10 EVRM. ${ }^{21}$ Anderzijds heeft de Hoge Raad de verspreiding van drukwerk, waarin op grond van Bijbelteksten werd betoogd dat de joden - door het niet erkennen van Jezus als de Messias - de Holocaust over zichzelf hebben afgeroepen, beoordeeld in het licht van de vrijheid van godsdienst. ${ }^{22}$ Of uitlatingen (mede) beschermd worden door de vrijheid van godsdienst, hangt volgens de Hoge Raad af van het antwoord op de vraag of zij "kenbaar in direct verband met de uiting van de geloofsopvatting staan'. ${ }^{23}$ Dat kan bijvoorbeeld gelden voor bepaalde negatieve uitlatingen over homoseksualiteit, wat overigens niet uitsluit dat deze tegelijkertijd deel uitmaken van het maatschappelijk debat. ${ }^{24}$

16 EHRM 4 december 2003, 35071/97 (Müslüm Gündüz/Turkije).

17 ECRM 16 mei 1977, 7050/75 (Arrowsmith/Verenigd Koninkrijk). Deze Commissie vormde in het verleden het voorportaal voor het EHRM.

18 EHRM 18 januari 2001, 41615/98 (Zaoui/Zwitserland) (ontv. besl.).

19 Het Hof heeft overigens ook affiches op de openbare weg die aanmoedigden tot het bezoeken van een levensbeschouwelijke site op grond van art. 10 EVRM beoordeeld, ook al was er volgens het Hof geen sprake van een bijdrage aan het maatschappelijk debat, EHRM (GK) 13 juli 2012, 16254/06 (Mouvement Raëlien Suisse/Suisse).

20 Ook bij S.C. van Bijsterveld, 'De controversiële godsdienst- en meningsuiting', Ars Aequi 2003, p. 533 e.v, worden vrijheid van meningsuiting resp. godsdienst niet uitdrukkelijk onderscheiden.

21 ABRvS 14 juli 2010, ECLI:NL:RVS:2010:BN1135.

22 HR (civiel) 5 juni 1987, ECLI:NL:HR:1987:AB9113, NJ 1988/702, m.nt. E.A. van der Alkema; HR (straf) 18 oktober 1988, ECLI:NL:HR:1988:AD0464, NJ 1989/476, m.nt. G.E. Mulder.

23 HR 9 januari 2001, ECLI:NL:HR:2001:AA9368, NJ 2001/203 (Van Dijke); HR 9 januari 2001, ECLI:NL:HR:2001:AA9367, NJ 2001/204, m.nt. J. de Hullu; HR 14 januari 2003, ECLI:NL:HR: 2003:AE7632, NJ 2003/261 m.nt. P.A.M. Mevis. In de conclusie van de A-G in de zaak-Van Dijke (HR 9 januari 2001, ECLI:NL:HR:2001:AA9368, NJ 2001/203) en bij de rechtbank in de zaak-El Moumni (Rb. Rotterdam 8 april 2002, ECLI:NL:BROT:2002:AE1154, Mediaforum 2002, p. 192-193) vinden we wél het eerdergenoemde criterium 'naar objectieve maatstaven een directe uitdrukking'.

24 Het Hof Arnhem achtte de uitlating van een evangelistenpaar dat homoseksuele omgang altijd tot besmetting en dood leidt overigens geen verkondiging van het geloof, omdat de bewering kenbaar onjuist en onzorgvuldig was. Hof Arnhem 9 februari 1988, NJCM-Bulletin 1989, p. 322. Cassatieberoep verworpen, HR 2 februari 1990, ECLI:NL:HR:1990:AB7894, NJ 1991/289. Overigens zij gezegd dat de Goeree's hun positie ondermijnden door zelf de ongerijmdheid van hun uitlatingen over aids te erkennen. 


\section{Beperkingsmogelijkheden}

Het belang van de vraag welke uitlatingen gedekt worden door de vrijheid van meningsuiting en welke (ook) door de vrijheid van godsdienst, moet overigens niet overschat worden. De beperkingsvoorwaarden bij artikel 9 en 10 EVRM ontlopen elkaar niet veel. Een inmenging is geoorloofd indien deze is voorzien bij wet, en indien deze noodzakelijk is in een democratische samenleving ten behoeve van een van de in het tweede lid genoemde doeleinden. Die doeleinden lopen weliswaar op een punt uiteen, ${ }^{25}$ maar daar staat tegenover dat de voorwaarde van een legitiem doel vrijwel nooit het struikelblok vormt bij de toetsing aan artikel 9 of artikel 10 EVRM. Het belangrijkste is veelal of de beperking als proportioneel beschouwd kan worden.

De vrijheid van meningsuiting heeft overigens niet bij iedere uitlating hetzelfde gewicht. Voor een beperking van het maatschappelijk debat zullen veelal zwaarwegender motieven aangevoerd moeten worden dan voor een beperking die bijvoorbeeld op reclame ziet. Uit de arresten van de Hoge Raad ten aanzien van godsdienstig geïnspireerde uitlatingen lijkt opgemaakt te kunnen worden dat de eis van relatief zwaarwegende motieven ook geldt voor beperkingen die zien op uitlatingen gedaan in het kader van de uiteenzetting van de geloofsovertuiging. ${ }^{26}$

\section{Misbruik van recht}

Wanneer we spreken over de verhouding tussen de vrijheid van godsdienst en meningsuiting enerzijds en radicale uitlatingen anderzijds, dan dient ook enige aandacht besteed te worden aan artikel 17 EVRM. Deze 'misbruik van recht'bepaling komt er kortheidshalve op neer dat er geen beroep mogelijk is op de in het verdrag vastgelegde rechten indien vrijheden misbruikt worden in een streven om de verdragsrechten te vernietigen. ${ }^{27}$ De bepaling kan zowel zien op de gekozen middelen als op de nagestreefde veranderingen. ${ }^{28}$

$\mathrm{Zij}$ is in het verleden toegepast op antisemitische stromingen, op een oproep alle moslims het Verenigd Koninkrijk uit te zetten, en op het verheerlijken van terrorisme. Hier is relevant dat ook de klacht van de vereniging Hizb ut Tahrir al Islam door het EHRM als misbruik van recht is gekwalificeerd. Het Hof refereerde zowel aan de antidemocratische doeleinden van de vereniging als aan het in elk geval

25 In art. 9 EVRM ontbreekt 'de nationale veiligheid'; dat is volgens het EHRM niet een toevalligheid, het belang van religieus pluralisme wordt op deze wijze nog een benadrukt, EHRM 12 februari 2009, 2512/04 (Nolan en K./Rusland). Art. 10 EVRM kent op zijn beurt echter weer 'de bescherming van de openbare orde' als beperkingsgrond.

26 Betaalde radioboodschappen die opriepen tot het bezoeken van godsdienstige bijeenkomsten werden door het EHRM 10 juli 2003, 44179/98 (Murphy/Ierland) beoordeeld in het kader van art. 10 EVRM.

27 Overigens is het in het algemeen niet duidelijk waarom het Hof art. 17 soms wel en soms niet toepast, H. Cannie \& D. Voorhoof, 'The abuse clause and freedom of expression in the European Human Rights Convention', NQHR 2011, 1, p. 54 e.v.

28 Vgl. A. Buyse, 'Contested Contours, the limits of freedom of expression from an abuse of rights perspective', in: E.Brems \& J.Gerards (red.), Shaping rights in the ECHR, Cambridge: University Press 2014, p. 197. 
niet afwijzen van het gebruik van geweld. Het propageren van de jihad kan derhalve binnen de reikwijdte van artikel 17 EVRM vallen. ${ }^{29}$

De bescherming van de democratie kan ook bij een beoordeling van uitlatingen op grond van artikel 10 of 11 EVRM (verenigingsvrijheid) een grote rol spelen. In het bekende Refah Partisi-arrest overweegt het Hof bijvoorbeeld dat de invoering van de sharia onverenigbaar is met uitgangspunten van de democratie, die aan het verdrag ten grondslag liggen. ${ }^{30}$ Mede om die reden komt het Hof tot de conclusie dat het partijverbod in kwestie noodzakelijk in een democratische samenleving geacht kon worden. Daar dient overigens aan toegevoegd te worden dat het Hof uitdrukkelijk vermeldt dat partijvorming op godsdienstige grondslag op zichzelf wel degelijk is toegestaan.

\section{Resumé}

Godsdienstig geïnspireerde uitlatingen die als de verkondiging van de geloofsovertuiging zijn te kenmerken of daarmee kenbaar in direct verband staan, vallen (tevens) binnen de reikwijdte van de vrijheid van godsdienst. Andere religieus geïnspireerde uitlatingen worden doorgaans door de vrijheid van meningsuiting beschermd. Overigens dienen zowel beperkingen van de vrijheid van godsdienst als beperkingen van de vrijheid van meningsuiting aan het vereiste te voldoen dat de beperking noodzakelijk is in een democratische samenleving.

\section{Opruiing en bedreiging}

In de vorige paragraaf is de grondrechtelijke bescherming van religieus geïnspireerde uitlatingen onderzocht. In deze en de volgende paragrafen kantelt het perspectief. Er komt een reeks uitingsdelicten voor het voetlicht, alsmede de toepassing daarvan op uitlatingen die (mede) godsdienstig gemotiveerd kunnen zijn. Uiteraard is er in het bijzonder aandacht voor de vraag in hoeverre de beperkingen zich verdragen met de grondrechtelijke bescherming.

Opruien tot strafbare feiten of tot gewelddadig optreden tegen het openbaar gezag is strafbaar op grond van artikel 131 van het Wetboek van Strafrecht (Sr). Onder strafbare feiten vallen uiteraard ook terroristische misdrijven. ${ }^{31}$ Artikel $131 \mathrm{Sr}$ is meermalen toegepast op jihadistische uitlatingen, zoals het plaatsen van filmpjes van aanslagen op internet, vergezeld van oproepen tot de jihad. ${ }^{32}$ Het is niet beslissend of de filmpjes of teksten door de verdachte zelf zijn vervaardigd of opgesteld. Ook het (verder) verspreiden van opruiende uitlatingen, die van anderen afkomstig zijn, is namelijk strafbaar.

30 EHRM 13 februari 2003, 41340/98, 41342/98, 41343/98 en 41344/98 (Refah Partisi e.a./Turkije).

31 Met het openbaar gezag wordt het Nederlandse openbaar gezag bedoeld; dat kan overigens ook in het geding zijn indien een uitlating mede betrekking heeft op het openbaar gezag in een ander land. HR 3 juli 2012, ECLI:NL:2012:HR:BW5132. 
Zo werd een combinatie van jihadistische YouTube-filmpjes met een foto van de verdachte met een kalasjnikov en de tekst 'wij zijn beide strijders', alsmede andere afbeeldingen die gekoppeld kunnen worden aan de jihad in Syrië, eveneens als opruiing gekwalificeerd. De rechtbank oordeelde dat 'de boodschap - in elk geval indirect - een duidelijke oproep tot het plegen van terroristische misdrijven' behelst. ${ }^{33}$ In deze zaak deed de verdediging een beroep op de vrijheid van meningsuiting. De rechtbank was van oordeel dat dit beroep afstuitte op artikel 17 EVRM, de misbruik van recht-bepaling: 'artikel 10 van het EVRM biedt geen schuilplaats aan hen die opruien tot terroristische misdrijven dan wel geschriften die daartoe opruien verspreiden'.

De Rechtbank Den Haag trekt in een recent vonnis de grens tussen toelaatbare en strafbare uitlatingen als volgt. Blijken van steun voor het streven van IS zijn niet strafbaar, evenmin als het verheerlijken van de gevoerde strijd. Gaat dat echter over in het verheerlijken van deelname aan die strijd, het prediken dat afreizen naar Syrië een nastrevenswaardig doel is en een martelaarsdood aldaar navolging verdient, dan wordt het anders. Uitlatingen van dien aard kunnen als opruiing worden gekwalificeerd en kunnen dus strafbaar zijn. ${ }^{34}$

Het is overigens niet steeds duidelijk in hoeverre genoemde uitlatingen direct voortvloeien uit de godsdienstige overtuiging van de verdachte of door hem daardoor gelegitimeerd worden. ${ }^{35} \mathrm{Er}$ is mij ook geen beroep op de vrijheid van godsdienst bekend. Wel maakte de Rechtbank Rotterdam een onderscheid tussen het geven van algemene lessen in de geloofsleer, wat toegestaan is, en het geven van lessen in het met geweld bestrijden van ongelovigen, wat strafbaar kan zijn. Indien er al dan niet op grond van teksten van de Koran wordt opgeroepen tot daden die bij uitvoering strafbare feiten opleveren, is er volgens de rechtbank sprake van opruiing. ${ }^{36}$

Er is eveneens een aantal gevallen van bedreiging met geweld (art. 285 Sr.), een delict dat anders dan de opruiing niet het vereiste van openbaarheid kent. Een voorbeeld is een e-mail met daarin onder meer de zinsneden: 'Zolang de Islam bestaat zul jij moeten vluchten' en 'Wij zullen afrekenen met jullie allen. De strijders van de Islam en de soldaten van Allah zullen de Islam in praktijk brengen en elke vijand van de Islam kennis laten maken met het zwaard'. ${ }^{37}$ Meer recent en tot op zekere hoogte vergelijkbaar is een videoclip waarin Geert Wilders werd bedreigd. De clip bevat onder meer de zinsnede 'Maar spotten met geloof, dan vraag je toch om moord', en aan het einde wordt de suggestie van een executie gewekt. $^{38}$

Sommige uitlatingen bestaan uit een combinatie van bedreiging en opruiing. Dat was het geval bij de verdachte die de opvatting was toegedaan dat er met geweld

Rb. Den Haag 1 december 2014, ECLI:NL:RBDHA:2014:14652.

Rb. Den Haag 10 december 2015, ECLI:NL:RBDHA:2015:14365, r.o. 12.65.

Zie voor de verschillende motieven van de jihadganger (strijden tegen onrecht, geloof, avontuur?): N. Platje, 'Jihadgang naar Syrië, een wetenschappelijke benadering', TvV 2014, 4, p. 35 e.v.

Rb. Rotterdam 30 oktober 2007, ECLI:NL:RBROT:2007:BB7174.

Vgl. ook Rb. Den Haag 23 maart 2010, ECLI:NL:RBSGR:2010:BN6708.

Rb. Den Haag 7 november 2014, ECLI:NL:RBDHA:2014:13583. 
een wereldwijd islamitisch rijk gesticht diende te worden. Hij had op internet een tekst geplaatst waarin hij opriep tot het creëren van haat tegen en het doden van de Kamerleden Hirsi Ali en Wilders, samen met een oproep tot het plegen van gijzelingen en een staatsgreep. De verdachte, die volgens de rechtbank overigens verminderd toerekeningsvatbaar was, werd schuldig bevonden aan bedreiging en opruiing. ${ }^{39}$

Bij opruiing en bedreiging is de verwevenheid met godsdienstige motieven voor de strafbaarheid in het algemeen van ondergeschikt belang. Daarvoor bestaat een aantal samenhangende redenen. De verwevenheid betekent op zichzelf nog niet dat er een beroep kan worden gedaan op het recht op vrijheid van godsdienst. Als er wél sprake is van een uitlating die kennelijk voortvloeit uit de geloofsovertuiging, valt te denken aan de mogelijkheid van misbruik van recht. Nog los daarvan zorgt die verwevenheid niet voor een vermindering van het strafwaardig karakter. Het belang om - de dreiging met - geweld te voorkomen is zo zwaarwegend, dat het belang van de vrijheid van godsdienst, als daar al een beroep op mogelijk is, of van de vrijheid van meningsuiting onvoldoende gewicht in de schaal legt.

Wel zijn er twee kanttekeningen mogelijk. De eerste is dat de opvatting dat gewapende strijd gerechtvaardigd is, zeker niet per se strafwaardig is. Over de vraag of een bepaald regime desnoods met geweld verdreven moet worden, kunnen de meningen uiteenlopen. ${ }^{40}$ Een dergelijke nuancering geldt uiteraard niet voor het oproepen tot terroristische daden. Deze problematiek speelt ook een rol in de recente zaak die bij de Rechtbank Den Haag diende. ${ }^{41}$ De rechtbank komt tot het oordeel dat het in 2012 in het openbaar oproepen tot deelname aan strijdgroepen die tegen Assad strijden, naar Nederlands recht als opruiing gekwalificeerd kan worden. ${ }^{42}$ Dat zou dus ook kunnen gelden voor oproepen tot deelname aan 'democratische' strijdgroepen die in Syrië tegen het bewind van Assad strijden. De gevolgde redenering leidt daarmee wel tot een vergaande beperking van de vrijheid van meningsuiting. ${ }^{43}$ In deze zaak gaat het verder overigens vrijwel steeds om deelname aan strijdgroepen die zich aan terroristische daden schuldig maken. ${ }^{44}$ In de tweede plaats valt erop te wijzen dat bepaalde godsdienstige rituelen en leerstukken op hun eigen merites moeten worden beoordeeld. Een religieuze bijeenkomst ter nagedachtenis aan omgekomen PKK-strijders zal niet te snel als het oproepen tot terrorisme kunnen worden gekwalificeerd. ${ }^{45}$ Uitlatingen over de verschrikkelijke toorn van het Opperwezen vormen nog geen opruiing of bedreiging. Dat kan anders zijn indien een dergelijk leerstuk verbonden wordt met con-

39 Rb. Middelburg 14 februari 2005, ECLI:NL:RBMID:2005:AS5730; overigens ook schuldig bevonden aan de voorbereiding van een terroristische daad.

40 Men vergelijke hier de reden van de regering om een voorbehoud te maken bij art 20 lid 1 IVBPR; er kunnen ook rechtvaardige oorlogen zijn.

41 Rb. Den Haag 10 december 2015, ECLI:NL:RBDHA:2015:14365, r.o. 7.29.

42 Hier wordt niet ingegaan op het verschil in implicatie op het moment dat er sprake is van een internationaal gewapend conflict, zie daarvoor het vonnis.

43 Dat is temeer zo, nu het oproepen tot deelname aan de kant van Assad niet als opruiing gekwalificeerd kan worden.

44 Idem, r.o. 8.10-8.11.

45 EHRM 2 december 2014, 31706/10 (Güler/Turkije). 
crete gebeurtenissen of personen. Zo lijkt de uitlating 'De moord op van Gogh is de wil van Allah en Wilders zou ook zoiets kunnen overkomen' een grensgeval. ${ }^{46}$ Deze uitlating lijkt in elk geval strafbaar te kunnen zijn indien zij wordt voorafgegaan door de uitlating dat moslims de wil van Allah moeten uitvoeren of indien zij gemaild wordt aan Wilders. ${ }^{47}$

\section{Resumé}

De belangen gemoeid met het voorkomen van opruiing en bedreiging zijn in het algemeen groot genoeg om een beperking van de vrijheid van meningsuiting te rechtvaardigen. Wat de verhouding met de vrijheid van godsdienst betreft, zijn er twee varianten. De eerste is dat opruiing en bedreiging per definitie buiten de reikwijdte daarvan vallen. De tweede is dat een beperking van die vrijheid om zwaarwegende redenen gerechtvaardigd is. Beide varianten kruisen elkaar waar het oproepen tot of het dreigen met het gebruik van geweld als misbruik van recht te kenmerken is.

\section{Groepsbelediging en haatzaaien}

Artikel 137c Sr verbiedt het in het openbaar beledigen van een groep wegens ras, godsdienst of levensovertuiging, hetero- of homoseksuele gerichtheid, of handicap. In artikel 137d Sr is het aanzetten tot haat, discriminatie of geweld tegen genoemde groepen, aangevuld met een groep wegens geslacht, strafbaar gesteld. Deze bepalingen zijn een aantal malen toegepast op uitlatingen gericht tegen gelovigen, ${ }^{48}$ maar in deze bijdrage ligt de nadruk op tegen derden gerichte, godsdienstig gemotiveerde uitlatingen. ${ }^{49}$

Wat de belediging (art. 137c Sr) betreft, is van belang dat in de rechtspraak een drietrapstoets wordt gehanteerd. ${ }^{50}$ Eerst wordt vastgesteld of bepaalde bewoordingen op zichzelf beledigend zijn; is dat het geval, dan moet onderzocht worden of de context het beledigende karakter aan de uitlatingen kan doen ontvallen. Daarbij dient gedacht te worden aan de context van het maatschappelijk debat, maar ook aan de context van de uiteenzetting van de geloofsovertuiging. Wel zij gezegd dat de genoemde contexten niet het gebruik van onnodig grievende bewoordingen rechtvaardigen. Deze zijn dus sowieso strafbaar.

Voor zover het om godsdienstig gemotiveerde uitlatingen gaat, valt in het bijzonder ook te denken aan de mogelijke belediging van homoseksuelen. De context van het uiteenzetten van de geloofsovertuiging - en van het maatschappelijk

46 Vgl. Y. Buruma, 'Moslimradicalisme en het strafrecht', DD 2005, 3, p. 267.

47 Zie bijv. ook Rb. Den Haag 10 december 2015, ECLI:NL:RBDHA:2015:14365, r.o. 20.4.

48 Wat dat betreft, is van belang dat een uitlating pas beledigend kan zijn in de zin van de strafbepaling indien zij onmiskenbaar over een groep gaat. Kritiek, van welke aard dan ook, op opvattingen of gedragingen wordt niet door de strafbepaling bestreken. HR 10 maart 2009, ECLI:NL:HR: 2009:BF0655.

49 Zie M. Berger, 'Religieuze grenzen aan de vrijheid van meningsuiting: de Deense spotprenten voor de Nederlandse rechter', in NJCM-Bulletin, 2006, 5, p. 664-675.

50 Bijv. HR 15 april 2003, NJ 2003/334; Hof Amsterdam 17 november 2006, ECLI:NL:GHAMS: 2006:AZ 3011. 
debat - zorgde er onder meer voor dat de vergelijking tussen homoseksualiteit en diefstal de delictsomschrijving niet vervulde. ${ }^{51}$ De verkondiging van de religieuze moraal wordt door deze bepaling op zichzelf dus niet belemmerd. Dat wordt anders indien de bewoordingen onnodig grievend zouden zijn, bijvoorbeeld indien gesproken wordt over 'homo's die wij vunzige flikkers noemen' ${ }^{52}$ Ook wanneer er suggestieve verbanden tussen homoseksualiteit en aids worden gelegd, vormen godsdienstige motieven geen grond om de uitlatingen niet onrechtmatig te achtten. ${ }^{53}$

In artikel $137 \mathrm{~d} \mathrm{Sr}$ is het verbod vastgelegd om in het openbaar aan te zetten tot haat tegen of discriminatie van mensen of tot gewelddadig optreden tegen mensen wegens hun ras, hun godsdienst of levensovertuiging, hun geslacht, hun hetero- of homoseksualiteit of hun handicap. Daarbij kan een onderscheid gemaakt worden tussen het aanzetten tot geweld, tot haat en tot discriminatie. Het aanzetten tot geweld tegen bepaalde groepen wordt over het algemeen strafwaardig geacht, en voegt bovendien niet zo heel veel toe aan de reeds behandelde opruiing. Ook hier lijkt een beroep op de vrijheid van godsdienst weinig zinvol.

Bij het aanzetten tot discriminatie is het niet volledig duidelijk waar de grens precies loopt. Enerzijds heeft de Hoge Raad er in het SGP-arrest ${ }^{54}$ expliciet op gewezen dat de SGP haar opvattingen over het verschil in roeping tussen man en vrouw en de maatschappelijke consequenties daarvan mag blijven uitdragen. Anderzijds zal een oproep om bepaalde groepen als minderwaardig te behandelen of buiten de samenleving te sluiten aan de delictsomschrijving kunnen voldoen. ${ }^{55}$ Gezien het belang van het uiteenzetten van de geloofsovertuiging of het bijdragen aan het maatschappelijk debat zullen waarschijnlijk alleen betrekkelijk vergaande uitlatingen de delictsomschrijving kunnen vervullen. ${ }^{56}$

Het op grond van met de godsdienst verweven motieven aanzetten tot haat heeft een rol gespeeld in de zaak tegen de Hofstadgroep. Het gerechtshof stelde eerst dat het vrijstaat de mening uit te dragen dat God de enige soeverein is, dat democratie en islam niet samengaan, dat een staatsbestel gebaseerd op de sharia veel beter is, en dat een moslim afstand moet houden van ongelovigen.

De door het strafrecht getrokken grenzen waren volgens het hof evenmin overschreden door een tekst waarin opgeroepen werd de ongelovigen te haten. Het hof overwoog dat met 'de ongelovigen' allen bedoeld zijn die niet de door de Hofstadgroep gevolgde variant van de islam aanhangen, dat wil zeggen een ruime meerderheid van de bevolking, voor de bescherming waarvan artikel $137 \mathrm{~d}$ Sr niet is bedoeld. De Hoge Raad zag daarin een onjuiste uitleg van de strafbepaling. De strafbepaling kan volgens de Hoge Raad dus ook zien op het door aanhangers van

51 HR 9 januari 2001, ECLI:NL:HR:2001:AA9368, NJ 2001/203; HR 9 januari 2001, ECLI:NL:HR: 2001:AA9367, NJ 2001/204; HR 14 januari 2003, ECLI:NL:HR:2003:AE7632, NJ 2003/261. Zie ook Hof Den Haag 18 november 2002, NJ 2003/24.

52 Vgl. Hof Amsterdam 17 november 2006, ECLI:NL:GHAMS:2006:AZ3011.

53 HR 2 februari 1990, ECLI:NL:HR:1990:AB7894, NJ 1991/289.

54 HR 9 april 2010, ECLI:NL:HR:2010:BK4549, NJ 2010/388.

55 Vgl. HR 16 december 2014, ECLI:NL:HR:2014:3583.

56 Vgl. Rb. Amsterdam 23 juni 2011, ECLI:NL:RBAMS:2011:BQ 9001 (Wilders). 
een relatief kleine geloofsstroming aanzetten tot haat tegen andersgelovige en ongelovige meerderheden. ${ }^{57}$

\section{Resumé}

Bij de opruiing en de bedreiging speelt het belang van de vrijheid van godsdienst en de vrijheid van meningsuiting een ondergeschikte rol. Dat is anders bij de toepassing van artikel 137c en d Sr. Dat is in het bijzonder het geval bij de groepsbelediging en het daarbij gehanteerde stappenplan. De verkondiging van radicale religieuze opvattingen lijkt op grond daarvan vooral in de gevarenzone te kunnen komen indien zij gepaard gaat met het gebruik van grove taal of met onjuiste feitelijke beschuldigingen.

De vraag in hoeverre genoemd stappenplan ook betekenis heeft bij de toepassing van artikel 137d Sr, kan niet eenduidig beantwoord worden. Het schetsen van godsdienstig geïnspireerde idealen lijkt op zichzelf niet snel als het aanzetten tot discriminatie of haat te kunnen worden gekwalificeerd. Dat kan anders zijn indien direct stemming wordt gemaakt tegen bepaalde groepen door deze te verketteren of als er bijvoorbeeld opgeroepen wordt de leden van een groep hun rechten te ontnemen. Al eerder was duidelijk geworden dat het aanzetten tot geweld, hoe religieus ingekleed dan ook, strafwaardig kan zijn.

\section{Ronselen}

Artikel 205 Sr bepaalt dat hij die, zonder toestemming van de Koning, iemand werft voor vreemde krijgsdienst of voor de gewapende strijd, strafbaar is. Tot een tiental jaren geleden zag de bepaling alleen op het 'aanwerven voor vreemde krijgsdienst'. Krijgsdienst werd elders in het wetboek omschreven als 'alle dienst die gewapenderhand optreden in een oorlog meebrengt en daarnaast dienst bij elke organisatie die naar het recht van het betrokken land tot de krijgsmacht behoort'.

Daardoor kon volgens de regering twijfel bestaan of de bepaling ook het aanwerven voor de 'jihad' bestreek. ${ }^{58}$ Met de wijziging in 'gewapende strijd' wordt zeker gesteld 'dat elk aanwerven voor een "jihad"' strafbaar is, ook als nog onduidelijk is 'of de geworvene zijn bijdrage aan deze strijd in enig georganiseerd verband zal willen leveren'. ${ }^{59}$ De jihad werd daarbij omschreven als 'islamitische strijd die de vorm aanneemt van het ontplooien van geweldsactiviteiten tegen gepercipieerde vijanden van de islam ter verwezenlijking van een wereld die een zo zuiver mogelijke afspiegeling is van hetgeen men meent dat in de eerste bronnen van het islamitische geloof - de koran en de soenna - staat vermeld'. Het daarbij beoogde gen in het publiek debat', DD 2008, 5/34. Men vergelijke overigens de expliciete vermelding van heteroseksualiteit in de bepalingen. 
geweld dient voor toepassing van de bepaling vergelijkbaar te zijn met 'het ingrijpend geweld dat wordt toegepast in een oorlogs- of guerrillasituatie'. ${ }^{60}$

De wetgever veranderde daarnaast het 'aanwerven' in 'werven'. Het eerstgenoemde begrip veronderstelde namelijk het op enigerlei moment tot stand komen van een verbintenis, met handgeld of andere voordelen als tegenprestatie. De wijziging zorgt ervoor dat ook het werven dat niet gericht is op een dergelijke verbintenis, strafbaar is. Een derde wijziging was de verhoging van de strafmaat van één tot vier jaar gevangenisstraf. ${ }^{61}$ De wetgever achtte dat strafmaximum te rechtvaardigen 'gelet op de mogelijk desastreuze gevolgen' van deze vorm van rekrutering 'voor de betrokkene en de mogelijke slachtoffers' ${ }^{62}$ Het derde lid hoogt de strafmaat bovendien nog op als de gewapende strijd waarvoor wordt geworven het plegen van een terroristisch misdrijf inhoudt. ${ }^{63}$

Door de wijziging heeft de bepaling een diffuser karakter gekregen. Was de ronselaar van oudsher te beschouwen als een vertegenwoordiger van een bepaalde strijdmacht die 'medewerkers' zocht, de huidige bepaling kan zich ook uitstrekken tot anderen die iemand trachten te 'werven'. De wetgever zelf spreekt daarbij over het 'bespelen' en 'beïnvloeden, het ideologisch rijp maken, bewegen of vergelijkbare handelingen', 'niet alleen op schoolpleinen en in clubhuizen en uitgaansgelegenheden, maar ook met behulp van moderne communicatiemiddelen' ${ }^{64}$

Daar staat tegenover dat het werven van personen wél dient te geschieden met het oog op hun rechtstreekse inzet ten behoeve van de islamitische of een anderszins gewapende en gewelddadige strijd ${ }^{65}$ als strijder, ${ }^{66}$ niet om het eventueel verrichten van ondersteunende (verzorging) taken. De Rechtbank Den Haag oordeelde daarom dat tot vrouwen gerichte uitlatingen niet als het werven voor de strijd in Syrië konden worden aangemerkt, nu 'de inzet van vrouwen op het slagveld door de belangrijkste jihadistische organisaties in Syrië, Jahbat-al-Nusra en ISIL, tot op heden niet vastgesteld (is) '. ${ }^{67}$ Berichten in de media wijzen er overigens op dat die situatie inmiddels veranderd zou kunnen zijn.

De Hoge Raad heeft voorts bevestigd dat de gedragingen van de werver centraal staan. Het is dus niet van belang of het werven succesvol is. Bovendien kan er van werven ook sprake zijn indien degene tot wie de uitlating is gericht de gewapende strijd reeds is toegedaan. ${ }^{68}$ Eveneens is in de rechtspraak bevestigd dat het wer-

60 Kamerstukken II 2003/04, 28463, 10, p. 12.

61 Kamerstukken II 2003/04, 28463, 8 (Tweede Nota van Wijziging).

62 Kamerstukken II 2003/04, 28463, 10, p. 8.

63 Het derde lid is ingevoerd met het oog op de implementatie van het ontwerp-kaderbesluit van de Raad tot wijziging van het Kaderbesluit 2002/475/JBZ van 13 juni 2002 inzake terrorismebestrijding.

64 Kamerstukken II 2003/04, 28463, 10, p. 11 en 16. Zie over het ronselen: M. van Leeuwen, 'Ronselen in Europa voor de Heilige Oorlog', JV 2005, 2, p. 84 e.v.

65 De werving moet daadwerkelijke deelname aan de strijd beogen; enkel financiële ondersteuning valt daar niet onder, Kamerstukken I 2003/04, 28463, C, p. 12.

66 Commissiebrief $2013 Z 07975$ AO DTN over ronselaars voor Syrië aan de Tweede Kamer, NCTV, 21 mei 2013.

67 Rb. Den Haag 1 december 2014, ECLI:NL:RBDHA: 2014:14648.

68 HR 15 november 2011, ECLI:NL:HR:2011:BP7585. 
ven ook in die zin minder concreet is dan het aanwerven, dat er geen concreet verzoek tot het deelnemen hoeft te zijn gedaan. ${ }^{69}$

Wat precies wel en niet als ronselen kan worden gekwalificeerd, is betrekkelijk uitgebreid aan de orde geweest in een zaak bij de Rechtbank Den Haag. ${ }^{70}$ De rechtbank beschouwde het louter steunen van iemand in zijn voornemen om naar Syrië te gaan niet als zodanig. Naar de mening van de rechtbank is er voor werven ook meer nodig 'dan het enkele praten over het geloof, over het al dan niet gerechtvaardigd zijn van een gewapende strijd, dan wel het verheerlijken van een gewapende strijd of van het uitspreken van steun daarvoor'. Werven impliceert naar het oordeel van de rechtbank dat een zekere stimulering van een persoon tot deelname aan de gewapende strijd is beoogd, en zal meestal een 'proceskarakter' hebben. Een eenmalige handeling, zoals in casu het in een chatgesprek proberen weg te nemen van gerezen twijfel over het strijden in Syrië, is mede daarom onvoldoende om de delictsomschrijving te vervullen. Meer in het algemeen zou het te ver voeren om de opvatting dat de strijd tegen Assad gerechtvaardigd is te verbieden, of deze opvatting nu een godsdienstige of een andere basis heeft.

Deze benadering komt vooralsnog terug in het proces tegen verdachten uit de Schilderswijk in Den Haag. Het Openbaar Ministerie heeft de tenlastelegging 'ronselen' laten vallen bij de verdachte die een aantal positieve opmerkingen over strijden in Syrië had gemaakt, zonder dat er van procesmatig overhalen sprake was. ${ }^{71}$ Uit het vonnis van de rechtbank in deze zaak blijkt overigens dat het bespelen en beïnvloeden, het ideologisch rijp maken, niet per se hoeft te worden afgesloten met een concreet verzoek tot deelname aan de gewapende strijd. ${ }^{72}$

\section{Resumé}

De uitleg die tot nu toe aan het 'ronselverbod' is gegeven, impliceert dat een godsdienstig gemotiveerd en enthousiast, maar algemeen pleidooi voor de vestiging van een kalifaat niet snel door de bepaling zal worden bestreken. Datzelfde geldt voor simpele blijken van sympathie voor strijdgroepen die daarnaar streven. Pas wanneer dergelijke uitlatingen overgaan in het - procesmatig - overhalen om actief aan de strijd deel te nemen, kan de delictsomschrijving vervuld zijn.

De huidige uitleg zorgt er dus voor dat de bepaling de vrijheid van godsdienst in het algemeen niet licht zal beperken. Dat is uiteraard anders indien men in het procesmatig overhalen tot de strijd bij uitstek een vorm van bekéren ziet. Daarin ligt eigenlijk besloten dat het strijden zelf ook als een vorm van belijden zou kunnen worden gezien. Dat zou nogal ver gaan; in dat geval kan bovendien aan de mogelijkheid van misbruik van recht gedacht worden. In elk geval is de samenhang met uitlating en gewelddaden zodanig groot dat een beperking van de vrijheid van godsdienst te rechtvaardigen is. 


\section{Verheerlijken van terrorisme}

In 2005 bracht de toenmalige minister van justitie, Donner, het idee naar voren om het verheerlijken van terrorisme strafbaar te stellen, net zoals dat in sommige andere Europese landen is gebeurd. Het voorstel stuitte echter op kritiek omdat de omschrijving te vaag zou zijn en mede daarom de vrijheid van meningsuiting te zeer zou kunnen beperken.

Tegen de achtergrond van de opmars van de strijdgroep ISIS in 2014 in Irak, die gepaard ging met daden van terreur, heeft nu de CDA-fractie in de Tweede Kamer bij monde van haar voorzitter het voornemen geuit om opnieuw met een voorstel voor strafbaarstelling te komen. De directe aanleiding vormde het zwaaien met ISIS-vlaggen tijdens demonstraties in Den Haag in de zomer van 2014. Deze uitlatingen geven volgens Buma niet alleen blijk van sympathie met de wandaden van ISIS, maar zouden bij uitstek ook een rol kunnen spelen in een gevaarlijk radicaliseringsproces. Daarnaast is gewezen op de onthoofdingsfilmpjes die op de sociale media verspreiding vinden, ook wel met enige instemming.

Om de betekenis van een dergelijke strafbepaling te analyseren, wenden we de blik naar Engeland. ${ }^{73}$ Daar bestaat sinds 2006 een strafbepaling die het doen van uitlatingen verbiedt die 'are likely to understood by some or all the members of the public as a direct or indirect encouragement or other inducement to the commission, preparation, or instigation of acts of terrorism'. Onder het indirect aanmoedigen valt onder meer de verheerlijking van terrorisme, waarbij de wetgever heeft aangetekend dat bijvoorbeeld het zoeken naar een verklaring voor terroristische daden niet als zodanig kan worden aangemerkt.

Uit een onderzoek van Marlies van Noorloos ${ }^{74}$ blijkt dat de bepaling de eerste acht jaar van zijn bestaan tot veertien veroordelingen heeft geleid. In het merendeel van de gevallen zou het zijn gegaan om uitlatingen die ook als opruiing zijn te kwalificeren. Een enkele maal was dat laatste niet het geval, zoals bij het verspreiden van een filmpje met de moord op een Engelse soldaat in Londen met een instemmend commentaar. Daarbij wees de rechter overigens in het bijzonder ook op het kwetsende karakter voor zijn familie. En ander voorbeeld betreft een combinatie van een publicatie over het werk van Qutb, een ideoloog van de Moslimbroederschap, interviews met familieleden van jihadisten en het onder verwijzing naar het lijden van de moslims goedpraten van Al Qaida. Juist in dit soort gevallen, waarin alleen van indirect aanmoedigen sprake is, kan men zich afvragen of de vrijheid van meningsuiting niet al te zeer onder druk kan komen te staan, mede omdat de getrokken grens niet duidelijk is.

Kijken we vanuit dat gezichtspunt naar het in Nederland gelanceerde voorstel, dan zal op zijn minst omschreven moeten worden wat het verheerlijken en/of vergoelijken van terrorisme is. Bij daden als de recente aanslagen in Parijs en ont-

73 M. van Noorloos, 'Verheerlijking van terrorisme: een nieuwe kans?', NJB 2014, 37, p. 1907 e.v. Zie ook het proefschrift van M. van Noorloos, Hate Speech Revisited. A comparative and historical perspective on hate speech law in the Netherlands and England \& Wales, Antwerpen: Intersentia 2011. 
hoofdingen van gijzelaars is dat vrij duidelijk, maar in andere gevallen hoeft daar geen overeenstemming over te bestaan. Een in bepaalde opzichten vergelijkbare vraag is in hoeverre het op dit moment in abstracto verheerlijken van het streven naar de vestiging van een kalifaat onder een dergelijke strafbepaling zou vallen. Enerzijds is zo'n staat een binnen de islam van oudsher bestaand ideaal; men zou zelfs van een 'islamitische utopie' kunnen spreken. ${ }^{75}$ Anderzijds wordt de strijd voor een dergelijke staat op dit moment met name gevoerd door de terreurgroep IS. Dat wil echter nog steeds niet zeggen dat enthousiasme voor het streven van IS de terroristische daden verheerlijkt.

Een volgende vraag is wat verheerlijken of vergoelijken is. Valt het tonen van begrip voor bepaalde gedragingen daar ook al onder? Komt bijvoorbeeld de uitlating dat het Palestijnse volk zodanig onderdrukt wordt dat het begrijpelijk is dat het zich met alle mogelijke middelen verzet ook in de gevarenzone?

Dat het trekken van een grens moeilijk is, blijkt bij uitstek ook uit de eerdergenoemde vlaggenkwestie. Er bestaan namelijk tal van vlaggen met daarop de tekst die de kern van de islamitische geloofsbelijdenis vormt: 'Er is geen god dan Allah' en 'Mohammed is zijn boodschapper'. Deze tekst staat bijvoorbeeld ook op de vlag van Saudi-Arabië. ${ }^{76}$ Het ligt niet voor de hand dat iedere vlag met deze tekst voor een verbod in aanmerking komt. Om die reden stelde burgemeester Van der Laan van Amsterdam dan ook dat er bij demonstraties een onderscheid valt te maken tussen (zwarte) vlaggen met deze tekst en meer in het bijzonder de ISISvlag: een zwarte vlag met het eerste deel van de tekst in witte letters op die zwarte achtergrond en het tweede deel van de tekst in zwarte letters in een witte cirkel.

Hij ging er daarbij van uit dat het zwaaien met de ISIS-vlag strafbaar is omdat het als aanzetten tot haat tegen bijvoorbeeld vrouwen en andersgelovigen kan worden aangemerkt. Het in de inleiding genoemde actieprogramma neemt daarentegen het standpunt in dat de strafbaarheid mede zal moeten blijken uit andere meegevoerde teksten. De Rechtbank Den Haag heeft inmiddels geoordeeld dat het enkele zwaaien met een IS-vlag wel als verheerlijking van de strijd van IS aan te merken is, maar daarmee nog niet als strafbare opruiing kan worden gekwalificeerd. ${ }^{77}$

$\mathrm{Nu}$ ging het in dezen om de toepassing van bestaande strafbepalingen, maar de onduidelijkheden lijken alleen maar groter te worden indien het verheerlijken c.q. het vergoelijken van terrorisme strafbaar wordt gesteld.

Deze bezwaren mogen overigens niet verhullen dat het EHRM een beperking van de vrijheid van meningsuiting wegens het verheerlijken van geweld of het verheerlijken van terrorisme onder omstandigheden wel degelijk toelaatbaar acht. Het Hof stelt daarbij zelf vast of een bepaalde uitlating inderdaad inspireert tot geweld, ${ }^{78}$ en het laat de nationale autoriteiten vervolgens een zekere beoorde-

75 M. de Koning, 'Moge Hij onze ogen openen. De radicale utopie van het 'salafisme”, TvRRB 2011, 2, p. 47 en 57.

76 Het erbij afgebeelde zwaard maakt deze vlag eigenlijk suggestiever.

77 Rb. Den Haag 10 december 2015, ECLI:NL:RBDHA:2015:14365, r.o. 12.10-12.11.

78 EHRM 8 juli 1999, 26682/95 (Sürek/Turkije (nr. 1)); EHRM (GK) 8 juli 1999, 23168/94 (Karatas/Turkije). 
lingsruimte om vast te stellen of een verbod op zijn plaats ${ }^{79}$ is. De vraag of een beperking noodzakelijk is, zal daarbij moeilijk beantwoord kunnen worden zonder te letten op de situatie waarin de uitlating wordt gedaan. ${ }^{80}$

\section{Resumé}

Bij strafbaarstelling van het verheerlijken dan wel het vergoelijken van terrorisme kan de afbakening van de reikwijdte voor problemen zorgen. Ziet de bepaling op uitlatingen die aanmoedigen om bepaalde terreurdaden te begaan, dan is zij in beginsel overbodig, nu dergelijke uitlatingen al snel onder opruiing vallen. Praat de uitlating terreurdaden tegen bepaalde bevolkingsgroepen goed, dan kan het geldend recht, in het bijzonder het verbod aan te zetten tot haat, veelal ook soelaas bieden.

Een verbod heeft dus alleen zin wanneer het tevens andersoortige uitlatingen bestrijkt. Op dat moment is het niet onmogelijk dat (ook) de vrijheid van godsdienst in het geding is. Een heftige uiteenzetting over de puurheid van het geloof, de heilige plaatsen en de Amerikaanse satan, enkele dagen na een terreuractie, zou wellicht in de gevarenzone kunnen komen. Datzelfde zou kunnen gelden voor een op de uitleg van de Koran gestoelde uiteenzetting waarin de strijd voor een kalifaat wordt toegejuicht.

Beperkt men de reikwijdte daarentegen tot het expliciet en enthousiast verheerlijken van concrete terreurdaden, dan blijft er niet zoveel over, tenzij men het 'liken' van een onthoofdingsfilmpje op zichzelf al strafwaardig acht. Voor meer expliciete pleidooien die dergelijke daden goedkeuren en verheerlijken lijkt geen nieuwe strafbepaling nodig, omdat deze al snel in de buurt van het aanzetten tot haat dan wel de opruiing zullen komen.

\section{Intrekken verblijfsvergunning/weigeren visum}

De eerder behandelde strafbepalingen stellen een aantal grenzen aan het verkondigen van extremistische opvattingen. Los daarvan is het verkondigen van sterk afwijkende, orthodoxe, fundamentalistische opvattingen toegestaan. Wel bestaat er, als gezegd, bezorgdheid dat dergelijke opvattingen een voedingsbodem kunnen vormen voor verdergaande radicalisering. ${ }^{81}$ De stelling dat bijvoorbeeld het salafisme geweld produceert, is echter net zo simplistisch als de stelling dat er geen enkel verband kan zijn. ${ }^{82}$ Zo beschouwd, is het logisch dat de AIVD onder omstandigheden ook interesse heeft in groeperingen die afwijzend staan tegenover de democratie, ook zonder dat zij expliciet oproepen tot 'harde acties' ${ }^{83}$

80 Bijv. EHRM (GK) 9 juni 1998, 22678/93 (Incal/Turkije); vgl. ook EHRM 2 oktober 2008, 36109/03 (Leroy/France).

81 Zie ook het in de inleiding genoemde Actieprogramma (NCTV 2014).

82 M. de Koning 2011, p. 47 en 57.

83 Op de door de AIVD genoemde dreigingen van geïslamiseerde enclaves met eigen wetten en de aantasting van het democratisch systeem wordt hier niet ingegaan. 
Deze ambiguïteit komt tot op zekere hoogte ook naar voren bij het weigeren van visa of het intrekken van verblijfsvergunningen. Dat is op grond van de Vreemdelingenwet mogelijk wanneer het verblijf 'een gevaar voor de nationale veiligheid' oplevert dan wel op zou kunnen leveren. De zaak betreffende een imam van de Al Fourkhan-moskee te Eindhoven vormt een goede illustratie. ${ }^{84}$ De minister had zijn besluit tot intrekking van diens verblijfsvergunning gebaseerd op een ambtsbericht van de AIVD. Daarin wordt geconcludeerd dat de imam, die te beschouwen was als een van de meest invloedrijke personen binnen de moskee, 'willens en wetens bijdraagt aan het propageren van exclusivisme en parallellisme en daarmee mede verantwoordelijk is voor het ontstaan van een voedingsbodem voor radicaal puritanisme en de vatbaarheid voor rekrutering voor de jihad'. De moskee was bovendien te beschouwen als een broedplaats voor radicalisering, en de imam was volgens de AIVD onvoldoende opgetreden tegen jihadistische elementen en de rekruteringen binnen Al Fourkhan. Het feit dat de preken op zichzelf niet in strijd zijn met de wet of rechtstreeks aanzetten tot geweld, deed daar niet aan af. In de procedure die volgde, overwoog de rechtbank dat de minister in redelijkheid tot de slotsom heeft kunnen komen dat eiser een gevaar vormt voor de nationale veiligheid en dat verweerder eiser ongewenst heeft kunnen verklaren. ${ }^{85}$

In een tot op zekere hoogte vergelijkbare zaak was de rechter er juist van uitgegaan dat de imam niet verantwoordelijk kon worden gehouden voor de rekruteringsactiviteiten in en rondom de moskee en dat het louter prediken van een radicale dawa onder de vrijheid van godsdienst valt en op zichzelf geen gevaar voor de nationale veiligheid oplevert. De enkele mogelijkheid dat de preken en andere uitlatingen van de imam bij bezoekers van de moskee hebben kunnen leiden tot (versterking van hun) radicale opvattingen en tot jihadistisch geweld, was volgens de rechter onvoldoende voor de conclusie dat de imam een gevaar voor de nationale veiligheid vormde. ${ }^{86}$

Deze uitspraken schetsen een dilemma. Enerzijds zou het streven radicalisering te voorkomen wellicht gebaat kunnen zijn met maatregelen om de prediking van de radicale dawa zo veel mogelijk tegen te gaan. Anderzijds is het prediken van bepaalde varianten van het salafisme op zichzelf niet verboden. Zolang er niet aangezet wordt tot haat, niet wordt opgeruid of bedreigd, niet wordt geronseld en niet onnodig grievend wordt beledigd of aangezet tot haat, is er geen strijd met de wet.

Daar moet onmiddellijk aan toegevoegd worden dat de vraag of iemand een gevaar vormt voor de nationale veiligheid, niet samen hoeft te vallen met het begaan van uitingsdelicten. Ook sterke vermoedens dat iemand sympathiseert met het gewelddadig jihadistisch gedachtegoed ${ }^{87}$ of dat iemand aanhanger is van bepaalde jihadistische organisaties kunnen voldoende zijn. Bovendien gaat de

Rb. Den Haag 2 november 2006, ECLI:NL:RBSGR:2006:AZ1371.

Rb. Den Haag 28 juli 2011, ECLI:NL:RBSGR:2011:BR3903. 
rechter er in het algemeen van uit dat de AIVD de deskundige instantie is om vast te stellen of iemand een gevaar vormt voor de nationale veiligheid. ${ }^{88}$

Bij het niet verstrekken van visa spelen vergelijkbare vraagstukken. Begin 2015 trok minister Koenders op basis van nadere informatie van de Nationaal Coördinator Terrorismebestrijding en Veiligheid (NCTV) de visa in van drie imams die waren uitgenodigd voor een bijeenkomst in Rijswijk. Het zou gaan om een bewonderaar van Osama bin Laden, een sympathisant van terreurorganisatie Al Qaida, en een derde, die banden zou hebben met jihadisten in Syrië. Dit soort sprekers zou een radicaliserend effect kunnen hebben. ${ }^{89}$ De minister stelde dat de weigering paste in het kader van het in de inleiding van deze bijdrage genoemde actieprogramma 'Integrale Aanpak Jihadisme'.

Het is wel de vraag welke rol de ophef in de media in dit soort zaken soms speelt. Wanneer de minister zich daardoor zou laten leiden, zou dat miskennen dat de vrijheid van godsdienst juist ook bestaat voor groeperingen met sterk afwijkende opvattingen. De nadruk bij het intrekken van het visum in het voornoemde geval dient zo beschouwd eerder op de bijkomende informatie (louche connecties) te liggen dan op het feit dat er radicale uitlatingen verwacht mochten worden

\section{Resumé}

Het uiten van radicale of orthodoxe godsdienstige opvattingen is pas strafbaar indien het binnen de reikwijdte van een van de eerder beschreven strafbepalingen valt. Ook als dat niet het geval is, kan er toch voldoende reden zijn om bepaalde stromingen en groeperingen 'in de gaten te houden' omdat zij een rol kunnen spelen bij een verdergaande radicalisering van met name jongeren. ${ }^{90}$

Ten aanzien van buitenlandse imams die radicale standpunten uitdragen, is het mogelijk dat voldaan is aan het criterium 'een gevaar op kunnen leveren voor de nationale veiligheid' zonder dat hun uitlatingen per se strafbaar hoeven zijn. Daarbij is het niet geheel overtuigend om alleen op het radicale karakter van bepaalde uitlatingen te wijzen. Wel kunnen louche connecties of het onvoldoende tegengaan van 'jihadistische' ontwikkelingen rondom een moskee een voldoende reden vormen om (verder) verblijf niet toe te staan.

\section{Conclusie}

Bepaalde uitlatingen zijn in Nederland verboden. Een dergelijke beperking van de vrijheid van meningsuiting zal niet snel op bezwaren stuiten indien er sprake is van opruiing, het aanzetten tot geweld of bedreiging. De mogelijkheid dat dergelijke uitlatingen worden ingegeven door een radicale godsdienstige overtuiging, rechter neemt kennis van onderliggende stukken niet per se inzage onderliggende door betrokkene.

89 E. Isitman, Visa van drie haatimams 'jihadgala' Rijswijk ingetrokken, 17 februari 2015, www.elsevier. nl/Politiek/achtergrond/2015/2/Koenders-trekt-visa-van-omstreden-imams-in-1708438W, geraadpleegd op 18 maart 2015.

90 Bijv. Y. Buruma 2005, p. 271; B. de Graaf 2011. 
verandert daar weinig aan. Óf religieuze motieven impliceren nog niet dat de uitlatingen binnen de reikwijdte van de vrijheid van godsdienst vallen, óf de beperking van de vrijheid van godsdienst is op grond van zwaarwegende motieven geoorloofd.

In geval van groepsbelediging en aanzetten tot discriminatie houdt de rechter wél rekening met de vrijheid van meningsuiting, met name wanneer de gewraakte uitlating een bijdrage aan het maatschappelijk debat vormt. Bij controversiële godsdienstig gemotiveerde uitlatingen die een onderdeel vormen van de uiteenzetting van de geloofsovertuiging, kan de vrijheid van godsdienst dezelfde rol spelen. Dat betekent niet dat er geen grenzen zijn, maar dat die pas worden overschreden wanneer er bijvoorbeeld sprake is van onnodig grievende uitlatingen.

Sommige delictsomschrijvingen zijn nadrukkelijk ingegeven door de mogelijkheid dat juist godsdienstig geïnspireerde uitlatingen ernstige gevolgen kunnen hebben. Dat geldt in de eerste plaats het werven voor de gewapende strijd; de wijziging van de strafbepaling is volledig betrokken op de jihad. Ook hier lijkt weer een onderscheid mogelijk tussen de uiteenzetting van de geloofsovertuiging, waarvan het verkondigen van het ideaal van de kalifaat deel kan uitmaken, en uitlatingen zoals het werven voor de gewapende strijd, die directer met het gebruik van geweld verbonden zijn. Dat sluit niet uit dat de verkondiging van de geloofsovertuiging een eerste stap in het proces van werven zou kunnen vormen, maar dat alleen is onvoldoende om de delictsomschrijving te vervullen. Voor zover iemand claimt dat het werven voor de jihad juist een integraal onderdeel is van het verkondigen van zijn geloofsovertuiging, kan gewezen worden op artikel 17 EVRM, de bepaling misbruik van recht.

In deze bijdrage is voorts aandacht besteed aan het voorstel om de verheerlijking en/of het vergoelijken van terrorisme strafbaar te stellen. Dat voorstel is mede door de onbepaaldheid op de nodige kritiek gestuit. Een risico voor de vrijheid van godsdienst zou kunnen zijn dat godsdienstige opvattingen, alleen omdat ze een radicaal karakter hebben en zouden kunnen dienen ter vergoelijking van geweld, in de gevarenzone komen.

Dat sluit niet uit dat radicale stromingen, die als voedingsbodem kunnen dienen voor nog verdergaande ideeën en handelingen, aandacht krijgen van de AIVD. Ook auteurs die een ruime vrijheid van godsdienst voorstaan, achten het niet onbegrijpelijk dat de AIVD dergelijke stromingen en/of moskeeën in de gaten houdt. Het verschil tussen securiteren en criminaliseren blijft echter wel relevant. Het verkondigen van sterk afwijkende, al dan niet orthodoxe, opvattingen van allerlei aard is immers om principiële grondrechtelijke redenen toegestaan.

Bij het weigeren of intrekken van een visum c.q. verblijfsvergunning ligt de zaak wat diffuser, maar blijft het onderscheid tussen strafbare en (andere) radicale uitlatingen van belang. Louter het verkondigen van controversiële opvattingen lijkt, zonder bijkomende omstandigheden, geen goede reden voor het intrekken van een verblijfsvergunning. In discussies over het verlenen of weigeren van een visum zou evenmin gesuggereerd moeten worden dat het verkondigen van dergelijke opvattingen eigenlijk al strafwaardig is. Daar staat tegenover dat er in veel gevallen meer aan de hand lijkt te zijn; contacten met bepaalde organisaties of 
verdergaande uitspraken in het verleden kunnen, zeker in bepaalde gevallen, een grond vormen om een visum te weigeren.

Dit alles leidt tot het oordeel dat het in grote lijnen meevalt met de inperking van de vrijheid van godsdienstige verkondiging. Daar dienen wel twee kanttekeningen bij geplaatst te worden. In de eerste plaats is het aanzetten tot of het werven voor de gewelddadige strijd hier niet beschouwd als een onderdeel van de vrijheid van godsdienst. Als dat wel het geval zou zijn, dan is de inperking overigens in beginsel te rechtvaardigen, zeker wanneer die strijd mede bestaat uit het begaan van terroristische misdrijven.

In de tweede plaats kunnen gewelddadigheden die mede godsdienstig gemotiveerd worden het idee versterken dat afwijkende en radicale opvattingen als vanzelf tot radicale acties zullen leiden. Dat kan de druk doen toenemen om het verkondigen van bepaalde opvattingen in te perken, ook zonder dat er sprake is van oproepen tot geweld of haat. Op dat moment dient erop gewezen te worden dat grondrechten niet of niet alleen de functie hebben opvattingen of godsdiensten te beschermen, voor zover die niet op bezwaren stuiten bij de meerderheid. De betekenis van de grondrechten dient bij uitstek ook naar voren te komen indien er controversiële idealen uiteengezet worden of een sterk afwijkende moraal wordt gepredikt.

Daaruit volgt overigens weer niet dat aanhangers van een bepaalde godsdienstige stroming die strenge voorschriften kent, anderen zodanig mogen verketteren dat van aanzetten tot haat sprake is. Het betekent wel dat ook bij het streven de jihad tegen te gaan rekening gehouden dient te worden met de vrijheid van godsdienst - en de vrijheid van meningsuiting. Het enkele feit dat uitlatingen op maatschappelijke verontwaardiging stuiten of niet te rijmen zijn met bepaalde in Nederland aangehangen waarden, is op zichzelf onvoldoende voor een verbod. Bovendien kan een uitbreiding van de rol van het strafrecht ertoe leiden dat aanhangers van fundamentalistische stromingen die gebruik van geweld afwijzen over één kam geschoren worden met degenen die geweld voorstaan. 